\section{The Effect of Low Light Intensity and Temperature on Growth of Schefflera arboricola in Interior Landscapes}

\author{
Astrid Kubatsch ${ }^{1}$ and Heiner Grüneberg \\ Humboldt University Berlin, Institute for Horticultural Sciences, Section of \\ Horticultural Plant Systems-Ornamental Floriculture, Lentzeallee 55, 14195 \\ Berlin, Germany

\section{Christian Ulrichs \\ Humboldt University Berlin, Institute for Horticultural Sciences, Section Urban Horticulture, Lentzeallee 55, 14195 Berlin, Germany}

Additional index words. acclimatization, foliage plants, fresh and dry weight, chlorophyll, leaf thickness

\begin{abstract}
Schefflera arboricola was held in light- and temperature-controlled chambers for 6 months under three light intensities of $10 \mu \mathrm{mol} \cdot \mathrm{m}^{-2} \cdot \mathrm{s}^{-1}, 20 \mu \mathrm{mol} \cdot \mathrm{m}^{-2} \cdot \mathrm{s}^{-1}$, and $80 \mu \mathrm{mol} \cdot \mathrm{m}^{-2} \cdot \mathrm{s}^{-1}$ measured as photon flux density $(P F D)$. Plants also received three temperature regimes: $15{ }^{\circ} \mathrm{C}, 20{ }^{\circ} \mathrm{C}$, and $25{ }^{\circ} \mathrm{C}$. Reduced light intensity significantly decreased fresh and dry weight and increased chlorophyll content, but did not affect leaf thickness and palisade and spongy mesophyll parenchyma. High temperatures reduced fresh weight and significantly increased chlorophyll content and leaf thickness. The authors conclude that reduced photosynthetic energy flow at low light intensities (10 $\left.\mu \mathrm{mol} \cdot \mathrm{m}^{-2} \cdot \mathrm{s}^{-1}, 20 \mu \mathrm{mol} \cdot \mathrm{m}^{-2} \cdot \mathrm{s}^{-1}\right)$ could not be buffered by a downregulation of energy-consuming processes. Therefore the life span and quality of $S$. arboricola is reduced at such PFD values, especially at higher temperatures. Plants lose their marketability within 6 months.
\end{abstract}

Schefflera arboricola is a member of the family Araliaceae and one of the most popular foliage plants used to landscape interiors. Generally, low light intensities, typical for indoors, increase leaf drop and reduce leaf quality (Conover and Poole, 1977; Sawwan and Ghunem, 1999). However, there are differences among species grown under low light intensities. For example, when grown in shade, the fresh and dry weights of Peperomia obtusifolia increased (Shen and Seeley, 1983), but dry weight of Ficus benjamina was reduced (Collins and Blessington, 1982). The fresh weight of Hedera helix was unaffected by light intensity (Collins and Blessington, 1981), whereas when $F$. benjamina and Chamaedorea elegans were grown in shade, leaves had higher chlorophyll content than leaves of plants grown in the sun (Lance and Guy, 1992; Reyes et al., 1996). The leaf thickness of Pelargonium $\times$ hortorum was reduced by increasing temperatures from $10{ }^{\circ} \mathrm{C}$ to $32{ }^{\circ} \mathrm{C}$ (Armitage et al., 1981). In contrast, temperature had no significant influence on leaf thickness and mesophyll parenchyma of $F$. benjamina (Kubatsch et al.,

\footnotetext{
Received for publication 18 Apr. 2006. Accepted for publication 14 Jul. 2006.

This work was supported by Berliner Graduiertenförderung (NaFöG) and the Kommission für Frauenförderung at Humboldt University Berlin, Germany.

${ }^{1}$ To whom reprint requests should be addressed; e-mail astrid.kubatsch@rz.hu-berlin.de.
}

2005). In addition, the temperature optimum for growth parameters decreased as light intensity decreased (Björkman, 1980). High growth temperatures resulted in reduced light absorption rates because of thin palisade mesophyll parenchyma, and resulted in lower net photosynthetic rates (low dry matter production) in Pelargonium $\times$ hortorum (Armitage et al., 1981). The assimilation rate of Euphorbia pulcherrima and Chrysanthemum grandiflorum increased with raising temperature levels resulting from higher light absorption (Menne, 1992).

The objective of this study was to examine the effects of light intensity and temperature on $S$. arboricola under interior landscape conditions.

\section{Materials and Methods}

Schefflera arboricola 'Luseane' plants were planted in $12-\mathrm{cm}$-diameter pots and placed in a hydroponic substrate (Lecaton, Ø 4-8 mm). Plants were separately exposed to three different photon flux densities $(P F D$; $10 \mu \mathrm{mol} \cdot \mathrm{m}^{-2} \cdot \mathrm{s}^{-1}, 20 \mu \mathrm{mol} \cdot \mathrm{m}^{-2} \cdot \mathrm{s}^{-1}, 80$ $\left.\mu \mathrm{mol} \cdot \mathrm{m}^{-2} \cdot \mathrm{s}^{-1}\right)$ combined with three temperature regimes $\left(15^{\circ} \mathrm{C}, 20^{\circ} \mathrm{C}\right.$, and $\left.25^{\circ} \mathrm{C} \pm 1{ }^{\circ} \mathrm{C}\right)$ in climate chambers for 6 months. During darkness $(10 \mathrm{~h})$, temperature was lowered $2{ }^{\circ} \mathrm{C}$ in all treatments. Light for $14 \mathrm{~h} / \mathrm{d}$ was supplied by metal halide lamps (Osram, HQIR, $250 \mathrm{~W}$ ) located $1.20 \mathrm{~m}$ above the plants. Each chamber was set at a specific temperature but there were three PFD treatments in each chamber. Various light in- tensities were obtained by enclosing the plants with covers of white fleece shading cloth of various densities. Plants were maintained at $65 \pm 5 \%$ relative humidity tolerating changing vapor pressure deficits (VPDs). Plants were placed constantly in excessive water.

$P F D$ was measured at nine locations in each climate chamber at plant height using a LI-COR photometer with a quantum sensor. Fertilizer was applied every 4 weeks as a solution of $\mathrm{N}-\mathrm{P}_{2} \mathrm{O}_{5}-\mathrm{K}_{2} \mathrm{O}-\mathrm{MgO}$ to provide a nutrient concentration of $0.2 \%$.

After 6 months, samples were taken for analysis from the most recently matured leaves in the upper canopy. Chlorophyll content per gram fresh weight was analyzed by a method described by Metzner (1982). A leaf from each plant was weighed, oven-dried at $105{ }^{\circ} \mathrm{C}$ for $36 \mathrm{~h}$, and the dry weight was determined. For anatomical examinations, small, rectangular sections were cut at mid lamina, preserved in formalin-acetic acidalcohol and dehydrated in an ethanol series, and embedded in plastic (Technovit 7100 and hardener, Heraeus Kulzer GmbH, Werheim, Germany). Sections $4 \mu \mathrm{m}$ thick were stained with toluidin blue.

There were nine replicate plants per treatment. All results were subjected to analysis of variance using SPSS version 10.0 (1999) for Windows. Data were tested for normal distribution and homogeneity. The 5\% probability level was accepted to indicate significant differences among treatments. Normal distributed data with homogeneous variances were compared using Tukey's test. If data were not normally distributed, the KruskalWallis test and Nemenyi test were used.

\section{Results and Discussion}

High light intensities increased fresh and dry weights of $S$. arboricola but both decreased at high temperatures (Tables 1 and $2)$. Because respiration increases with temperature, a combination of low light and high air temperature can rapidly reduce available stored energy (Svenson, 2002). Decreased photosynthetic energy flow at low light intensities could not be buffered by a downregulation of energy-consuming processes (Pörs, 1999). Therefore the life span of $S$. arboricola may be reduced when light intensity is insufficient, especially at higher temperatures. However, fresh weight is not a very accurate parameter to describe growth of plants cultivated in soil, because it depends strongly on soil water availability (Taiz and Zeiger, 2002). The term water availability expresses the balance between the atmospheric water demand (equal to VPD) and the capability of the growing medium to supply this demand at the compatible rate. As such, water availability is a relative property that does not depend only on the levels of water content or tension in the growing medium but also on temperature and relative humidity. At higher temperatures (assuming a constant water supply where water is not limited and constant light intensity) we gain 
a higher VPD than at lower temperatures, and we expect a growth reduction as described for 'Boston' fern by Mortensen (1986) and confirmed by Dawson et al. (1991) for three fern cultivars grown at $30{ }^{\circ} \mathrm{C} / 25^{\circ} \mathrm{C}$ (day/night) at low or high VPD. We could confirm such results with decreasing leaf growth parameters reduced at higher temperatures when water supply was constantly available, and VPD increased at two different light intensities (Table 2). Water in the medium can be considered available, although not fully, if the pattern of water uptake rate follows the VPD daily pattern - namely, it does not decrease when VPD increases.

The overall changes of the plant photosystem in response to variations in the light environment for different plant species have been thoroughly described (Melis, 1996; Osmond, 1994). In our study, chlorophyll content was influenced by light intensity and temperature, and increased with temperature and the a-to-b ratio with light intensity respectively. An increase in accessory chlorophyll results in maximized light absorption rate (Evans, 1989). At low temperatures, the photosynthetic apparatus alters chloroplast development (Haldimann et al., 1995; Robertson et al., 1993). Hansen et al. (2002) and Kitajima and Hogan (2003) found a positive correlation between the chlorophyll $a-t o-b$ ratio and shade tolerance. Shade-grown plants have a lower chlorophyll a-to-b ratio than plants exposed to high light levels. In contrast, high chlorophyll b content (data not shown) reduced the ratio of chlorophyll a-to-b in $S$. arboricola leaves when exposed to high light intensities. The absorption of chlorophyll is very low in green light between $480 \mathrm{~nm}$ and $550 \mathrm{~nm}$. The so-called green gap of chlorophyll a is closed partially by absorption of the accessory pigment chlorophyll b. Therefore, light absorption by the antenna system improves the chlorophyll a-tob ratio at low light levels (Sitte et al., 2002).

Leaf thickness as well as palisade and spongy mesophyll parenchyma were not influenced by light intensity, but plants grown under higher temperature levels developed thicker leaves (Table 3). The increased leaf thickness is a result of an increase in palisade parenchyma, which is located directly under the upper epidermis. Because the cylindrical and elongated palisade cells contain chloroplasts and the palisade parenchyma is the main photosynthetic tissue of the leaf, we assume that photosynthesis was elevated at higher temperatures as a result of better enzyme kinetics. At $25{ }^{\circ} \mathrm{C}$ we also found significant higher chlorophyll content than at $15{ }^{\circ} \mathrm{C}$ and $20{ }^{\circ} \mathrm{C}$ (Table 1). However, Oguchi et al. (2003) found high photosynthetic rates without increased leaf thickness in mature leaves with increasing light intensity.

Plant response to temperature and light regimes differ even between species that are described in the literature with similar requirements such as $F$. benjamina and S. arboricola (Kubatsch and Ulrichs, 2005). High temperatures caused elongated intern-

Table 1. Effect of light intensity and temperature on leaf fresh and dry weights, and chlorophyll content of Schefflera arboricola leaves kept for 6 months.

\begin{tabular}{lcccc}
\hline & $\begin{array}{c}\text { Leaf fresh wt } \\
(\mathrm{mg})\end{array}$ & $\begin{array}{c}\text { Leaf dry wt } \\
(\mathrm{mg})\end{array}$ & \multicolumn{2}{c}{ Chlorophyll $\left(\mathrm{mg} \cdot \mathrm{g}^{-1}\right)$} \\
\cline { 4 - 5 } & & & Total & $\mathrm{a}-\mathrm{o}-\mathrm{b}$ ratio \\
\hline Light intensity $\left(\mu \mathrm{mol} \cdot \mathrm{m}^{-2} \cdot \mathrm{s}^{-1}\right)^{\mathrm{z}}$ & $0.76 \mathrm{a}$ & $0.09 \mathrm{a}$ & $67.00 \mathrm{~b}$ & $1.85 \mathrm{a}$ \\
10 & $1.31 \mathrm{~b}$ & $0.18 \mathrm{~b}$ & $69.56 \mathrm{~b}$ & $1.90 \mathrm{a}$ \\
20 & $1.72 \mathrm{c}$ & $0.29 \mathrm{c}$ & $57.04 \mathrm{a}$ & $1.96 \mathrm{~b}$ \\
80 & & & & \\
Temperature $\left({ }^{\circ} \mathrm{C}\right)^{\mathrm{y}}$ & $1.52 \mathrm{~b}$ & $0.23 \mathrm{~b}$ & $61.66 \mathrm{a}$ & $1.87 \mathrm{a}$ \\
15 & $1.13 \mathrm{a}$ & $0.16 \mathrm{a}$ & $61.37 \mathrm{a}$ & $1.87 \mathrm{a}$ \\
20 & $1.16 \mathrm{a}$ & $0.18 \mathrm{ab}$ & $69.84 \mathrm{~b}$ & $1.95 \mathrm{~b}$ \\
25 & & & & $*$ \\
Significance & $* *$ & $* *$ & $* *$ & $*$ \\
Light intensity $(\mathrm{L})$ & $* *$ & $* *$ & $* *$ & $*$ \\
Temperature $(\mathrm{T})$ & $* *$ & $* *$ & $*$ & $*$ \\
L $\times$ T & & & & $*$ \\
\hline
\end{tabular}

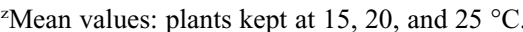

${ }^{\mathrm{y}}$ Mean values: plants kept at 10,20 , and $80 \mu \mathrm{mol} \cdot \mathrm{m}^{-2} \cdot \mathrm{s}^{-1}$.

${ }^{x}$ Mean separation within columns between treatments by *Tukey or **Kruskal-Wallis and Nemenyi test; $P<0.05$.

Table 2. Effect of temperature and light intensity regimes on plant growth parameters of Schefflera arboricola leaves kept for 6 months.

\begin{tabular}{lccc}
\hline $\begin{array}{l}\text { Temperature }\left({ }^{\circ} \mathrm{C}\right) / \text { light intensity } \\
\left(\mu \mathrm{mol} \cdot \mathrm{m}^{-2} \cdot \mathrm{s}^{-1}\right)\end{array}$ & $\begin{array}{c}\text { Leaf fresh wt } \\
(\mathrm{mg})\end{array}$ & $\begin{array}{c}\text { Leaf dry wt** } \\
(\mathrm{mg})\end{array}$ & $\begin{array}{c}\text { Leaf area* } \\
\left(\mathrm{cm}^{2}\right)\end{array}$ \\
\hline $15 / 80$ & $2.03 \mathrm{c}$ & $0.36 \mathrm{c}$ & $62.91 \mathrm{c}$ \\
$20 / 80$ & $1.55 \mathrm{~b}$ & $0.24 \mathrm{~b}$ & $44.97 \mathrm{ab}$ \\
$25 / 80$ & $1.57 \mathrm{~b}$ & $0.28 \mathrm{~b}$ & $45.90 \mathrm{ab}$ \\
$15 / 20$ & $1.54 \mathrm{~b}$ & $0.21 \mathrm{ab}$ & $51.67 \mathrm{~b}$ \\
$20 / 20$ & $1.55 \mathrm{~b}$ & $0.16 \mathrm{a}$ & $37.08 \mathrm{a}$ \\
$25 / 20$ & $1.21 \mathrm{a}$ & $0.17 \mathrm{a}$ & $33.65 \mathrm{a}$ \\
\hline
\end{tabular}

${ }^{z}$ Mean separation within columns between treatments by *Tukey or **Kruskal Wallis and Dunn test, $P<0.05$.

Table 3. Effect of light intensity and temperature on leaf thickness of Schefflera arboricola kept for 6 months at different light and temperature regimes.

\begin{tabular}{lccc}
\hline & Leaf thickness $(\mu \mathrm{m})$ & Palisade thickness $(\mu \mathrm{m})$ & $\begin{array}{c}\text { Spongy mesophyll } \\
\text { thickness }(\mu \mathrm{m})\end{array}$ \\
\hline $\begin{array}{l}\text { Light intensity } \\
\left(\mu \mathrm{mol} \cdot \mathrm{m}^{-2} \cdot \mathrm{s}^{-1}\right)^{\mathrm{z}}\end{array}$ & & & \\
10 & $285.68 \mathrm{a}$ & $74.97 \mathrm{a}$ & $127.06 \mathrm{a}$ \\
20 & $275.79 \mathrm{a}$ & $68.92 \mathrm{a}$ & $116.50 \mathrm{a}$ \\
80 & $310.31 \mathrm{a}$ & $75.73 \mathrm{a}$ & $132.39 \mathrm{a}$ \\
Temperature $\left({ }^{\circ} \mathrm{C}\right)^{\mathrm{y}}$ & & & \\
15 & $257.12 \mathrm{a}$ & $56.84 \mathrm{a}$ & $118.70 \mathrm{a}$ \\
20 & $289.54 \mathrm{~b}$ & $68.79 \mathrm{~b}$ & $123.71 \mathrm{a}$ \\
25 & $325.11 \mathrm{c}$ & $83.95 \mathrm{c}$ & $133.54 \mathrm{a}$ \\
Significance & & & \\
Light intensity $(\mathrm{L})$ & $\mathrm{NS}$ & $\mathrm{NS}$ & NS \\
Temperature (T) & $* *$ & $* *$ & NS \\
L $\times \mathrm{T}$ & $* *$ & $* *$ & \\
\hline
\end{tabular}

${ }^{2}$ Mean values: plants kept at 15,20 , and $25^{\circ} \mathrm{C}$.

${ }^{y}$ Mean values: plants kept at 10,20 , and $80 \mu \mathrm{mol} \cdot \mathrm{m}^{-2} \cdot \mathrm{s}^{-1}$.

${ }^{x}$ Mean separation within columns between treatments by **Kruskal-Wallis and Nemenyi test; $P<0.05$.

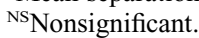

odes in F. benjamina but reduced internode length in $S$. arboricola. Both plant species differed also in their response to low light intensities. Low light intensities cause fall of leaves, elongated internodes in young shoots and very small leaves. $S$. arboricola should be exposed for $14 \mathrm{~h}$ at $5 \mu \mathrm{mol} \cdot \mathrm{m}^{-2} \cdot \mathrm{s}^{-1}$. The reduction of the light exposure time to $8 \mathrm{~h}$ increased the minimum requirement of light to $8 \mu \mathrm{mol} \cdot \mathrm{m}^{-2} \cdot \mathrm{s}^{-1}$

Below such light intensities, $S$. arboricola lose leaves and become unmarketable within a 6-month period. Another factor that has been found crucial for $S$. arboricola growth is maintaining a low VPD. Because a high relative humidity is not favorable under indoor conditions, plants need to be well watered to avoid water stress conditions.

\section{Literature Cited}

Armitage, A.M., W.H. Carlson, and J.A. Flore 1981. The effect of temperature and quantum flux density on the morphology, physiology, and flowering of hybrid geraniums. J. Amer. Soc. Hort. Sci. 106:643-647.

Björkman, O. 1980. Responses and adaptation of photosynthesis to high temperatures, p. 233249. In: C. Turner and P.J. Kramer (eds.). 
Adaptations of plants to water and high temperature stress Wiley Interscience, New York.

Collins, P.C. and T.M. Blessington. 1981. Influence of production and ancymidol on foliage plants. Hort. Sci. 16:215-266.

Collins, P.C. and T.M. Blessington. 1982. Postharvest effects of various light sources and duration on keeping quality of Ficus benjamina L. Hort. Sci. 17:908-909.

Conover, C.A. and R.T. Poole. 1977. Effects of cultural practice on acclimatization of Ficus benjamina L. J. Amer. Soc. Hort. Sci. 102:529-531.

Dawson, I.A., R.W. King, and R. van der Staay. 1991. Optimising conditions for growth of Nephrolepis ferns. Sci. Hort. (Amsterdam) 45:303-314

Evans, J.R. 1989. Photosynthesis and nitrogen relationships in leaves of $\mathrm{C} 3$ plants. Oecologia 78 : 9-19.

Haldimann, P., Y. Fracheboud, and P. Stamp. 1995. Carotenoid composition in Zea mays developed at sub-optimal temperature and different light intensities. Physiol. Plant 95:409-414.

Hansen, U., B. Fiedler, and B. Rank. 2002. Variation of pigment composition and antioxidative systems along the canopy light gradient in a mixed beech/oak forest: A comparative study on deciduous tree species differing in shade tolerance. Trees Structure Function 16:354-364.

Kitajima, K. and K.P. Hogan. 2003. Increases of chlorophyll $\mathrm{a} / \mathrm{b}$ ratios during acclimation of tropical woody seedlings to nitrogen limitation and high light. Plant Cell Environ. 40:857865 .
Kubatsch, A., H. Grüneberg, and C. Ulrichs. 2005. Acclimatization of Ficus benjamina to the temperature and irradiance conditions in interior landscapes. J. Appl. Bot. Food Qual 79:117-121

Kubatsch, A. and C. Ulrichs. 2005. Pflanzenakklimatisation an Temperatur- und Lichtbedingungen in Innenräumen. Gesunde Pflanzen 57:81-89.

Lance, C.J. and C.L. Guy. 1992. Chances in pigment levels, rubisco and respiratory enzyme-activity of Ficus benjamina during acclimation to low irradiance. Physiol. Plant 86:630-638

Melis, A. 1996. Excitation energy transfer:Functional and dynamic aspects of Lhc (cab) proteins, $p$ 523-538. In: D.R. Ort and C.F. Yocum (eds.) Advances in photosynthesis Vol. 4. Kluwer Academic Publishers, Dordrecht, The Netherlands.

Menne, A. 1992. Reaktion einiger Zierpflanzen auf mehrtägige Fluktuationen von Temperatur und Lichtintensität. University Hannover, Germany, $\mathrm{PhD}$ thesis.

Metzner, H. 1982. Pflanzenphysiologische Untersuchungen. Fischer Verlag, Stuttgart.

Mortensen, L.M. 1986. Effect of relative humidity on growth and flowering of some greenhouse plants. Sci. Hort. 29:301-307.

Oguchi, R., K. Hikosaka, and T. Hirose. 2003. Does the photosynthetic light-acclimation need change in leaf anatomy? Plant Cell Environ 26:505-512.

Osmond, C.B. 1994. What is photoinhibition? Some insights from comparisons of shade and sun plants, p. 1-24. In: Baker, N.R.,
J.R. Bowyer. (eds.). Photoinhibition of photosynthesis: From molecular mechanisms to the field. Bioscientific Publishers, Oxford, U.K.

Pörs, Y. 1999. Anpassung von Tabakpflanzen (Nicotiana tabacum L.) an Licht- und Chlorophyllmangel. Humboldt-Universität $\mathrm{zu}$ Berlin, Germany, $\mathrm{PhD}$ thesis.

Robertson, E.J., N.R. Baker, and R.M. Leech. 1993. Chloroplast thylakoid protein changes induced by low growth temperature in maize revealed by immunocytology. Plant Cell Environ. 16:809-818.

Reyes, T., T.A. Nell, J.E. Barrett, and C.A. Conover. 1996. Irradiance level and fertilizer rate affect acclimatization of Chamaedorea elegans Mart. Hort. Sci. 31:839-842.

Sawwan, J.S. and R.S. Ghunem. 1999. Light acclimatization of Schefflera arboricola. Adv. Hort. Sci. 13:151-155.

Shen, G.W. and J.G. Seeley. 1983. The effect of shading and nutrient supply on variegation and nutrient content of variegated cultivars of Peperomia obtusifolia. J. Amer. Soc. Hort. Sci. 108:429-433.

Sitte, P., E.W. Weiler, J.W. Kadereit, A. Bresinsky, and C. Körner. 2002. Strasburger - Lehrbuch der Botanik. Spektrum Akademischer Verlag, Heidelberg.

SPSS, Inc. 1999. SPSS base 10.0 Applications Guide. SPSS, Chicago.

Svenson, S.E. 2002. Shady business. Amer. Nurseryman 195:23-28.

Taiz, L. and E. Zeiger. 2002. Plant physiology. Palgrave Macmillan, Sunderland, Mass. 